\title{
ELECTRODEPOSITION OF ZnO NANOROD ARRAYS FOR APPLICATION IN PEROVSKITE BASED SOLAR CELLS
}

\author{
F.A. CATAÑO*, L.W. ALLENDE, H. GÓMEZ \\ Instituto de Química. Facultad de Ciencias, Pontificia Universidad Católica de Valparaíso, Av. Universidad 330, Curauma, Valparaíso, Chile.
}

\begin{abstract}
We report a low-cost, free-hole conductor methylammonium lead iodide $\mathrm{CH}_{3} \mathrm{NH}_{3} \mathrm{PbI}_{3}$ (perovskite)/ZnO nanorods (NR) heterojunction solar cell. ZnO nanorod arrays were obtained electrochemically onto transparent conducting oxide (fluor doped tin oxide, FTO) from an aqueous solution of zinc acetate. The ZnO NR were characterized by X-ray diffraction (XRD), scanning electron microscopy (SEM), and optical transmittance. Solar cell was fabricated forming the perovskite material onto the $\mathrm{ZnO}$ thin film. Spin coating of an equimolar mixture of $\mathrm{CH}_{3} \mathrm{NH}_{3} \mathrm{I}$ and $\mathrm{PbI}_{2}$ in $\gamma$-butyrolactone solution (perovskite precursor solution) leads to $\mathrm{CH}_{3} \mathrm{NH}_{3} \mathrm{PbI}_{3}$ formation on $\mathrm{ZnO}$ NR. A graphite-covered FTO/glass was used as a back contact. The photovoltaic performance of the solar cell was characterized at full sun intensity of $100 \mathrm{~mW} / \mathrm{cm}^{2}$ obtaining a shortcircuit current of $1.5 \mathrm{~mA} / \mathrm{cm}^{2}$, an open circuit voltage of $0.47 \mathrm{~V}$ and energy conversion efficiency of $0.16 \%$.
\end{abstract}

Keywords: Solar cells, Organic-Inorganic Perovskites, Zinc Oxide, Nanorods.

\section{INTRODUCTION}

Energy plays an important role in the economic future of countries. This problem is a global issue for our planet, aggravated by the fact that in the forthcoming decades, due to an increasing world population, energy demand will increase significantly. Conservative estimates implies that fossil fuels may be exhausted during the decade of $2040 \mathrm{~s}^{1}$, with the serious consequences that this entails. It is expected that in future, solar energy will play a major role as an alternative energy source. The Sun provides Earth with as much energy every hour as human civilization uses every year ${ }^{2}$. Therefore, harvesting a small fraction of incident solar irradiation could meet our growing energy demand. Realizing the full potential of this vast energy source requires a new generation of photovoltaics that are both efficient and cost-effective.

Nowadays, the cristallyne silicon solar cell corresponds to the most used photovoltaic technology. However, the manufacturing of this kind of solar cell demands a great amount of energy. Purifying and crystallizing the silicon are the most energy intensive parts of the solar cell manufacturing process. In this case the EPBT (Energy Payback Time, the length of time a PV system takes to generate the amount of energy put into system) is as long as 2.7 years.

Organic-inorganic perovskite-based solar cells have recently emerged as a transformative photovoltaic (PV) technology. Perovskite solar cells based on titanium dioxide, a $\mathrm{CH}_{3} \mathrm{NH}_{3} \mathrm{PbI}_{3}$ light-absorption layer and spiro-OMeTAD as hole transporting material have achieved power conversion efficiencies as high as $15.0 \%^{3}$, making it competitive with thin-film PV technology. Several reports suggest that solar cells with efficiencies up to $20 \%$ are realistically achievable $e^{4-5}$. The most attractive aspects of this technology are the simplicity of photoactive layer synthesis and application using benchtop approaches at temperatures less than $100^{\circ} \mathrm{C} .{ }^{6}$ Besides, the perovskite material exhibit optimal characteristic to be used as a light-absorption layer such as broad absorption spectra range with high extinction coefficient ${ }^{7}$, ambipolar diffusion ${ }^{8}$, and long carrier diffusion length ${ }^{9}$.

$\mathrm{TiO}_{2}$ has been one of the most studied wide band gap semiconductor photoanode in perovskite based solar cells. Alternatively, $\mathrm{ZnO}$ exhibits many advantages as a photoanode material compared to $\mathrm{TiO}_{2}$, such as a wide direct band gap and higher electron mobility $\left(\mathrm{ZnO} 100-205^{2} \mathrm{~cm}^{2} \mathrm{~V}^{-1} \mathrm{~s}^{-1} ; \mathrm{TiO}_{2} 0.1-1.0\right.$ $\left.\mathrm{cm}^{2} \mathrm{~V}^{-1} \mathrm{~s}^{-1}\right)^{10}$. The suitability of $\mathrm{ZnO}$ to prepare a variety of nanostructures has led to an important number of studies where vertically aligned, one dimensional 1-D nanostructures are utilized as photoanodes in solar cells sensitized with dyes ${ }^{11}$. These nanostructures favor electrons transport, contribute to diminish the electron-hole recombination and to improve the electron collection towards the external circuit due to the existence of a direct pathway free of boundary grains ${ }^{12}$.

Electrodeposition is a useful and simple technique to form $\mathrm{ZnO}$ nanostructures onto conducting substrates at lower temperatures and short deposition times ${ }^{13}$. Besides, it allows the modulation of the morphological and the structural characteristics of the deposits by simple changes in the synthesis conditions. Pradham and Leum ${ }^{14}$ electrochemically obtained a series of $\mathrm{ZnO}$ nanostructures varying the precursor concentration in the electrolytic solution. For $\mathrm{ZnO}$ nanowires, is possible to control the diameter and length of these nanostructrures by changes in concentration precursor and synthesis time ${ }^{15}$.
In current paper, highly oriented $\mathrm{ZnO}$ nanorods were prepared by electrodeposition from aqueous solutions containing $\mathrm{Zn}\left(\mathrm{CH}_{3} \mathrm{COO}\right)_{2}$ and $\mathrm{O}_{2}$ as precursors employing $\mathrm{CH}_{3} \mathrm{COONa}$ as supporting electrolyte. Nanorods presenting a strong crystallographic orientation along the (0002) crystalline plane were assembled as-grown as photoanode in a $\mathrm{CH}_{3} \mathrm{NH}_{3} \mathrm{PbI}_{3}$ perovskitebased solar cell. Photovoltaic property was tested at full sun intensity of 100 $\mathrm{mW} / \mathrm{cm}^{2}$. In spite of the low power conversion efficiency obtained, results open the possibility of improving it by introducing modifications in the solar cell architecture.

\section{EXPERIMENTAL}

\subsection{ZnO Electrochemical Deposition}

Zinc oxide NR were electrochemically grown onto FTO covered glass following a previous reported methodology ${ }^{13}$. Briefly, the electrodeposition of $\mathrm{ZnO} \mathrm{NR}$ arrays was performed in a three-electrode electrochemical cell with the FTO substrate as the working electrode, a $\mathrm{Zn}$ sheet as the counterelectrode, and a saturated calomel electrode (SCE) as the reference. The electrolyte was an aqueous solution of $1 \mathrm{mM} \mathrm{Zn}\left(\mathrm{CH}_{3} \mathrm{COO}\right)_{2}, 0.1 \mathrm{M} \mathrm{CH}_{3} \mathrm{COONa}$ and saturated with bubbling oxygen. The $\mathrm{ZnO} \mathrm{NR}$ arrays have been electrodeposited at 70 ${ }^{\circ} \mathrm{C}$ under potentiostatic conditions of $-1.000 \mathrm{~V}$ vs. SCE. The final samples were washed with deionized water to remove any residual salt. In order to obtain a more dense and compact $\mathrm{ZnO}$ thin film the electrodeposition time was longer (180 minutes) than that reported in reference 13.

2.2. Synthesis of $\mathrm{CH}_{3} \mathrm{NH}_{3} \mathrm{I}$

Methylammonium lead iodide was synthesized by the dropwise addition of hydroiodic acid (aqueous, $57 \mathrm{wt} \%$ ) to a solution of methylamine (aqueous, $40 \mathrm{wt} \%$ ) in an ice bath. The cold solution was stirred for $2 \mathrm{~h}$, and afterwards the solvent was evaporated at a temperature of $60^{\circ} \mathrm{C}$. The crystals were washed several times using diethyl ether, and then dried at ambient temperature. The white solid obtained was used without further purification.

2.3. Synthesis of PbI

Lead iodide was synthesized mixing equal volumes of $0.1 \mathrm{M} \mathrm{Pb}\left(\mathrm{NO}_{3}\right)_{2}$ and $0.2 \mathrm{M} \mathrm{KI}$. The yellow precipitated was filtered and washed with distilled and deionized water several times. Finally, the yellow solid was dried at a temperature of $50^{\circ} \mathrm{C}$.

\subsection{Deposition of $\mathrm{CH}_{3} \mathrm{NH}_{3} \mathrm{PbI}_{3}$ onto $\mathrm{ZnO} \mathrm{NR}$}

The $\mathrm{CH}_{3} \mathrm{NH}_{3} \mathrm{PbI}_{3}$ precursor solution was prepared by dissolving equimolar amounts of $\mathrm{CH}_{3} \mathrm{NH}_{3} \mathrm{I}$ and $\mathrm{PbI}_{2}$ in anhydrous $\gamma$-butyrolactone ( $36 \%$ by weight). This solution was dripped on top of $\mathrm{ZnO}$ NRs, and then spun at $1000 \mathrm{rpm}$. The film was placed on a hot plate at $80{ }^{\circ} \mathrm{C}$ under nitrogen atmosphere for $30 \mathrm{~min}$ to form crystalline $\mathrm{CH}_{3} \mathrm{NH}_{3} \mathrm{PbI}_{3}$.

2.5. Construction and testing of solar cell

FTO/glass covered with graphite was used as a back contact and sandwiched to the $\mathrm{FTO} / \mathrm{ZnO} / \mathrm{CH}_{3} \mathrm{NH}_{3} \mathrm{PbI}_{3}$ composite. A schematic representation of the solar cell is shown in Figure 1. J-V characterization was made in air using a $1000 \mathrm{~W}$ Xenon-Mercury lamp (Oriel 6295) and light intensity of $100 \mathrm{~mW} / \mathrm{cm}^{2}$. Infrared radiation was eliminated through a water filter and ultraviolet radiation was eliminated with a UV filter $(\lambda<400 \mathrm{~nm})$. Current-voltage characteristics of solar cells were recorded by a Keithley 2400 digital sourcemeter. 


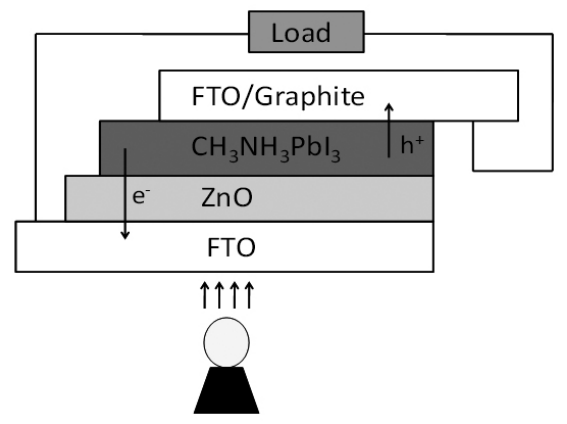

Figure 1. Schematic representation of the solar cell.

\subsection{Structural, morphological and optical characterization}

The structural characterization of $\mathrm{ZnO} \mathrm{NR}$ was carried through X-ray diffraction (XRD) measurements. Standard $\theta-2 \theta$ scans were performed on a Philips PW180 diffractometer $\left(30 \mathrm{kV}, 40 \mathrm{~mA}, \mathrm{CuK}_{\alpha}\right.$ radiation with $\lambda=1.5406$ $\mathrm{A}^{\circ}$ ). The diffraction peaks from $\mathrm{ZnO}$ and FTO have been indexed by reference to the JCPDS powder diffraction files. Before XRD measurements of FTO/ $\mathrm{ZnO} / \mathrm{CH}_{3} \mathrm{NH}_{3} \mathrm{PbI}_{3}$ system a film of gold/paladium was sputtered on perovskite side; this is necessary because perovskite is unstable in humid conditions. SEM images were recorded from a JEOL JSM/5900 LV SEM instrument. Optical properties were studied by Transmission spectroscopy using a UV/Visible SEC 2000 Espectra System spectrophotometer.

\section{RESULTS AND DISCUSSION} NR

\subsection{Structural, morphological and optical characterization of $\mathrm{ZnO}$}

$\mathrm{X}$-ray diffraction spectra of the electrochemically grown $\mathrm{ZnO}$ NR is show in Figure 2. The X-ray diffraction pattern reveal the presence of diffraction peaks related to the hexagonal wurtzite phase of $\mathrm{ZnO}^{16}$ and also those corresponding to the tetragonal $\mathrm{SnO}_{2}$ phase $^{17}$ of FTO/glass used as substrate. No other peaks were detected by XRD indicating only the formation of hexagonal $\mathrm{ZnO}$ phase. A substantially higher intensity is observed for the (0002) diffraction peak. This indicates that the $\mathrm{ZnO}$ NRs arrays were grown along the c-axis normal to the substrate, as we further confirmed by SEM observations.

Figure 3 show a top view and $45^{\circ}$ tilted SEM images of the ZnO NRs array. The ZnO NR arrays are dense and highly oriented. The statistical analysis of the NR diameter is also shown in Figure 3; the mean diameter is $420 \mathrm{~nm}$ with a standard desviation of $130 \mathrm{~nm}$. Comparing this values with the reported in previous studies ${ }^{13}$, our mean diameter is higher indicating that an increase in the deposition times lead to an increase in the diameter. Another noteworthy characteristic to highlight is the high nanorod density obtained $\left(1.22 * 10^{8} \mathrm{~cm}^{-2}\right)$.

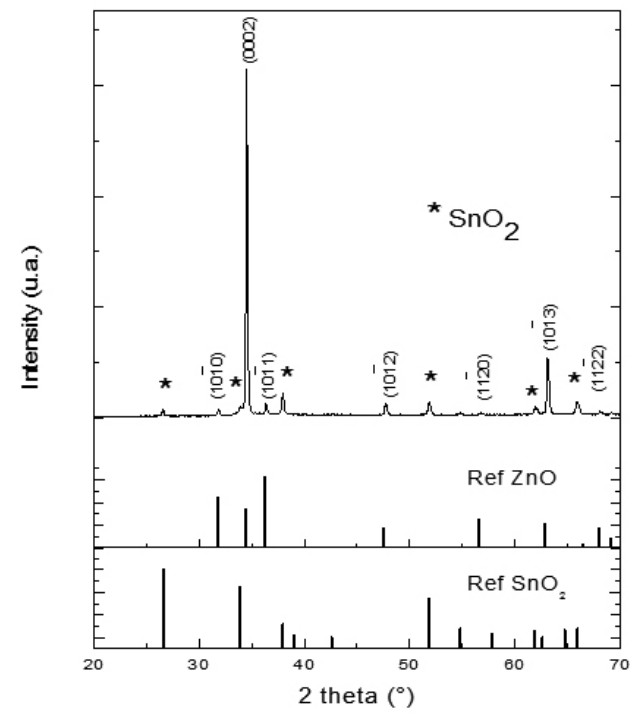

Figure 2. XRD patterns of $\mathrm{ZnO}$ NR arrays. Lower vertical bars corresponds to bulk $\mathrm{ZnO}$ and $\mathrm{SnO}_{2}$ JCPDS pattern. (*) indicates the peaks originated from the $\mathrm{SnO}_{2}: \mathrm{F}$ substrate.

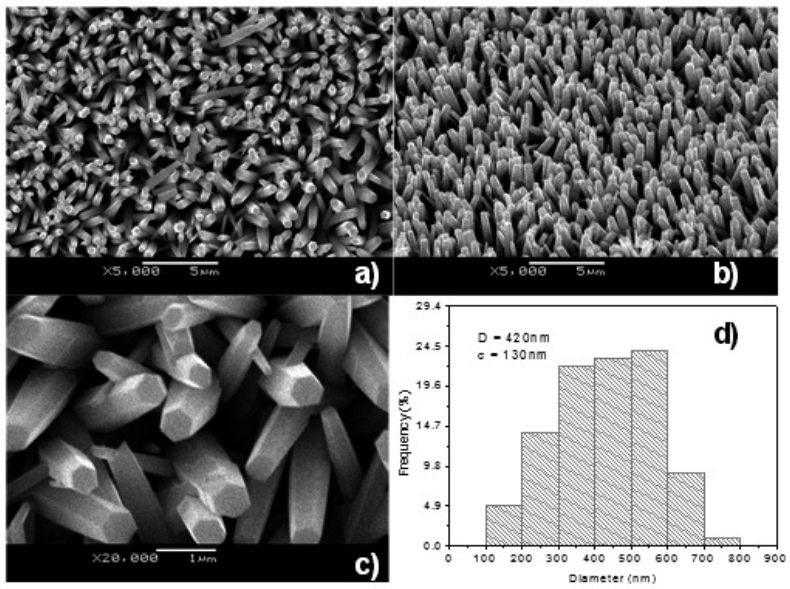

Figure 3. SEM images of $\mathrm{ZnO}$ NR arrays. a) top view, b) $45^{\circ}$ tilted view, c) top view (higher amplification), and d) statistics on NR diameter (D is mean diameter and $\sigma$ is standard deviation).

The UV-VIS transmittance spectra of the $\mathrm{ZnO}$ thin film is shown in Figure 4. The transmittance spectra shows an absorption band between 370 and $400 \mathrm{~nm}$ corresponding to electron transitions from the valence band to the conduction band.

The band gap energy of the electrodeposited $\mathrm{ZnO}$ thin film can be obtained in two different ways. The first method is the peak position in the graphic of $\mathrm{dT} / \mathrm{d} \lambda^{18}$ (first derivative of $T$ against wavelength $\lambda$ ). In effect, $\mathrm{dT} / \mathrm{d} \lambda$ (Figure 4) has a prominent peak in the region of the absorption band at $386.05 \mathrm{~nm}$, this correspond to a band gap energy of $3.21 \mathrm{eV}$.

The second method is to consider that for semiconductors presenting direct transitions, the bandgap energy can be obtained by a linear fitting from the $(\alpha h v)^{2}$ vs $h v$ plot, the energy value corresponds to the intercept with the abscissa. Besides, a background that account for any residual below-bandgap energy absorption, dispersion, or reflection must be take into account. This background or zero absorption associated to the band to band transitions is modeled like an indirect absorption coefficient ${ }^{18}$. The band gap energy obtained following this method, Figure 5, is $3.22 \mathrm{eV}$. The values obtained in the two methods are very similar and very close to the accepted room temperature bandgap energy of bulk $\mathrm{ZnO}$, which is between 3.2 and $3.4 \mathrm{eV}$ at room temperature ${ }^{19}$.

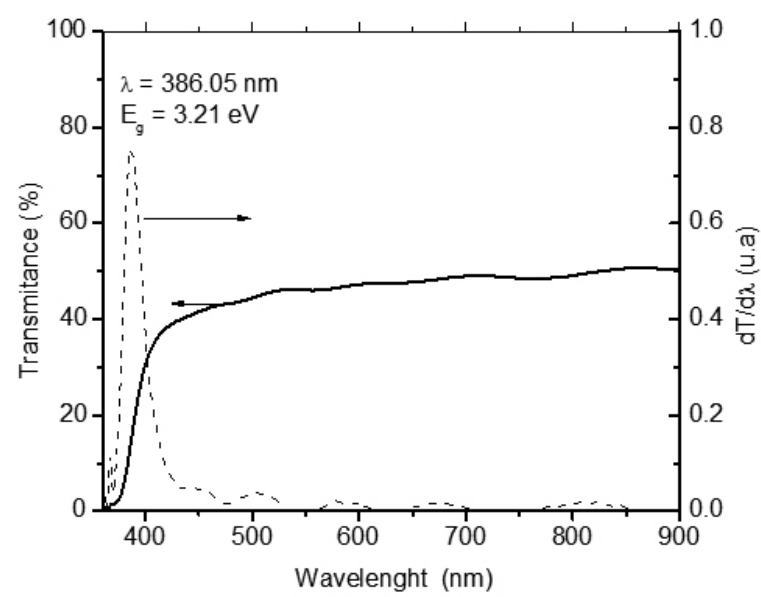

Figure 4. Transmittance spectra of $\mathrm{ZnO}$ thin films and its first derivative.

\subsection{Application to $\mathrm{ZnO} / \mathrm{CH}_{3} \mathrm{NH}_{3} \mathrm{PbI}_{3}$ based solar cell}

XRD analysis was performed in order to confirm the formation of $\mathrm{CH}_{3} \mathrm{NH}_{3} \mathrm{PbI}_{3}$ (Figure 6). Peaks are observed at approximately 2 theta values of $28.44^{\circ}, 31.72^{\circ}, 40.46^{\circ}$, and $42.72^{\circ}$, respectively corresponding to the reflections from (220), (310), (224), and (314) crystal planes of the tetragonal perovskite structure ${ }^{20}$. Also, peaks associated to the $\mathrm{Au} / \mathrm{Pd}$ sputtered film are 
observed. The peaks at 38.4 and $43.62^{\circ}$ are associated to (111) and (200) cristal planes of the cubic gold structure ${ }^{21}$, and the peak at $39.52^{\circ}$ is associated to (111) cristal plane of cubic palladium structure ${ }^{22}$. X ray difractions peaks of $\mathrm{SnO}_{2}$ and $\mathrm{ZnO}$ are also present.

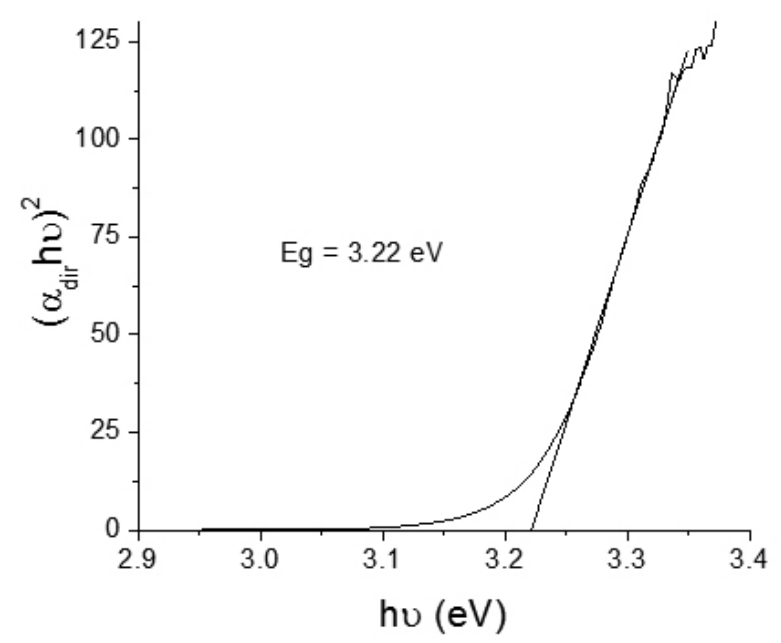

Figure 5. $\left(\alpha_{d i r} h v\right)^{2}$ vs $h v$ plot. The intercept with the energy axis is the band gap energy.

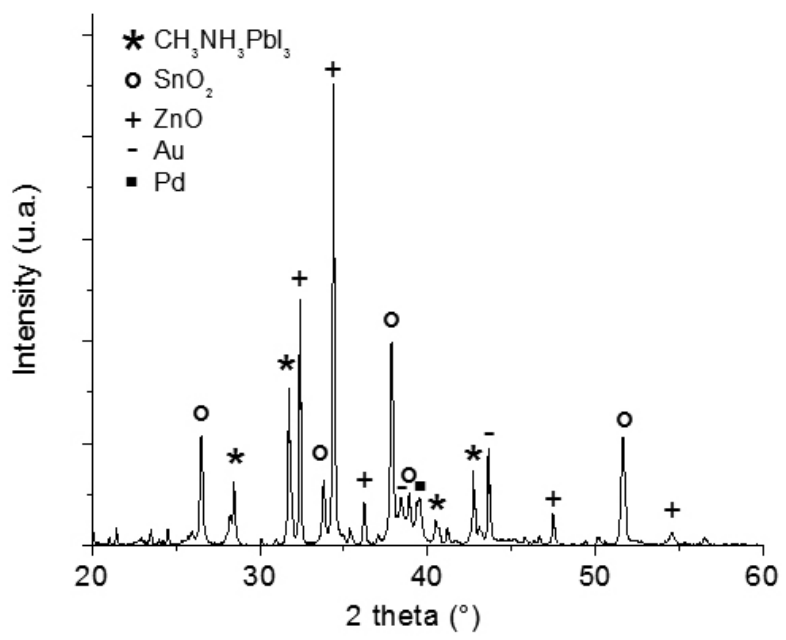

Figure 6. $\mathrm{X}$ ray diffraction pattern of the system $\mathrm{FTO} / \mathrm{ZnO} \mathrm{NR} /$ $\mathrm{CH}_{3} \mathrm{NH}_{3} \mathrm{PbI}_{3}$ perovskite/Au $\mathrm{Pd}$.

The $J-V$ property of the $\mathrm{CH}_{3} \mathrm{NH}_{3} \mathrm{PbI}_{3}$ perovskite/ZnO nanorods (NR) heterojunction solar cell is shown in figure 7 . The device is characterized by short circuit current of $1.5 \mathrm{~mA} / \mathrm{cm}^{2}$, open circuit voltage of $0.47 \mathrm{~V}$, fill factor of 0.23 and efficiency $0.16 \%$. The efficiency and fill factor are low compared to the reported values of perovskite based solar cell ${ }^{23}$. This can be attributed to the resistance to current flow from $\mathrm{CH}_{3} \mathrm{NH}_{3} \mathrm{PbI}_{3}$ perovskite to back contact which was made by pressing to a conducting glass covered with graphite. This assembly results in that the two faces are not in a suitable contact leading to an increase in charge carriers recombination and a voltage drop.

Typically, the back contact is made evaporating noble metals ( $\mathrm{Au}$ or $\mathrm{Ag}$ ), which is an expensive and complicated vacuum technology. Therefore, it is highly desirable to develop alternatives with good performance but inexpensive, environmentally friendly and easily procesable ${ }^{24}$. The back contact used in this work was selected as an alternative, but in view of the results of power efficiency conversion obtained the electrical contact between the parts need to be substantially improved.

As a final remark it is necessary to highlight that in terms of cost, the architecture of the solar cell reported has not considered the inclusion of a hole transporting material (HTM), usually a high cost material, for contributing to improve the cell efficiency. Work is currently in progress for including alternative low cost HTM in the cell architecture.

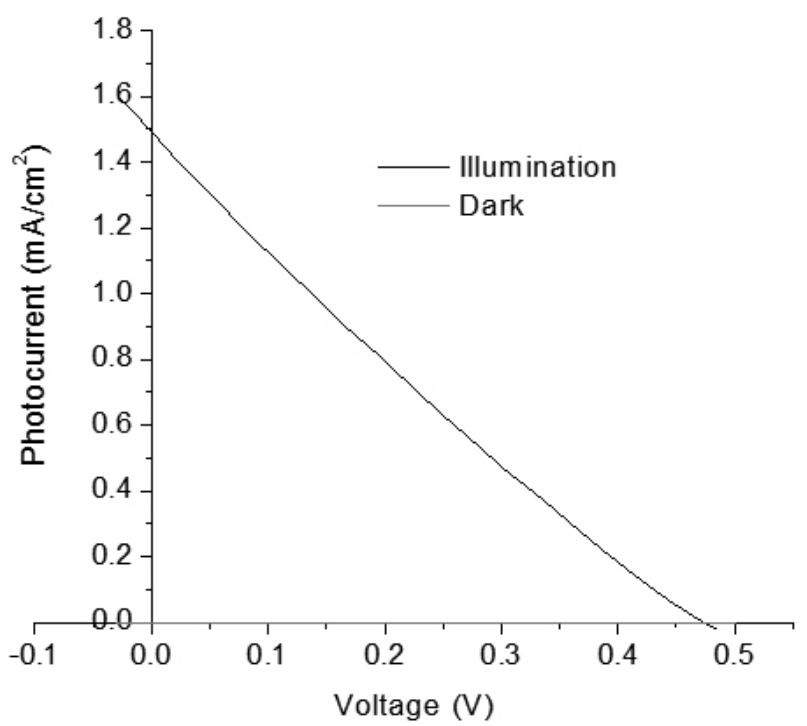

Figure 7. $\mathrm{J}-\mathrm{V}$ characteristic for $\mathrm{CH}_{3} \mathrm{NH}_{3} \mathrm{PbI}_{3}$ perovskite/ZnO nanorods (NR) heterojunction solar cell at full sun intensity of $100 \mathrm{~mW} / \mathrm{cm}^{2}$.

\section{CONCLUSIONS}

Highly oriented $\mathrm{ZnO}$ nanorods with c-axis preferred orientation were synthesized by electrodeposition and used as obtained in a low cost, freehole conductor methylammonium lead iodide $\left(\mathrm{CH}_{3} \mathrm{NH}_{3} \mathrm{PbI}_{3}\right)$ perovskite/ZnO heterojunction solar cell. The back contact was made sandwiched together a graphite covered $\mathrm{FTO} /$ glass and $\mathrm{CH}_{3} \mathrm{NH}_{3} \mathrm{PbI}_{3} / \mathrm{ZnO} / \mathrm{FTO}$ system as an alternative to the expensive back contact made by evaporation of noble metals. The low power conversion efficiency of the cell was attributed to the poor quality of the back contact a fact that is necessary to address in order to obtain better efficiencies.

\section{ACKNOWLEDGMENTS}

F.A.C. acknowledges to Vicerrectoría de Investigación y Estudios Avanzados, Pontificia Universidad Católica de Valparaíso for the postdoctoral scholarschip awarded.

\section{REFERENCES}

1. S. Shafiee, E. Topal, Energy Policy. 37, 181, (2009).

2. O. Morton, Nature. 443, 19, (2006).

3. J. Burschka, N. Pellet, S.J. Moon, R. Humphrey-Baker, P. Gao, M.K. Nazeeudderin, M. Gratzel, Nature. 499, 316, (2013).

4. N.G. Park, J. Phys. Chem. Lett. 4, 2423, (2013).

5. M.D. McGehee, Nature. 501, 323, (2013).

6. P.V. Kamat, J. Am. Chem. Soc. 136, 3713, (2014)

7. Q. Chen, H. Zhou, Z. Hong, S. Luo, H. S. Duan, H. H. Wang, Y. Liu, G. Li and Y. Yang, J. Am. Chem. Soc. 136, 622, (2014).

8. H.J. Snaith, J. Phys. Chem. Lett. 4, 3623, (2013).

9. G. Giorgi, J. Fujisawa, H. Segawa, K. Yamashita, J. Phys. Chem. Lett. 4, 4213, (2013).

10. Y. Li, W. Xie, X. Hu, G. Shen, X. Zhou, Y. Xiang, X. Zhao, P. Fang, Langmuir. 26, 591, (2010).

11. O. Lupan, V.M. Guérin, I.M. Tiginyanu, V.V. Ursaki, L. Chow, H. Heinrich, P. Pauporté, J. Photochem. Photobiol. A. 211, 65, (2010).

12. J. Anta, E. Guillen, R. Tena-Zaera J. Phys. Chem. C. 116, 11413, (2012).

13. C.D. Bojorge, V.R. Kent, E. Teliz, H.R. Cánepa, R. Henríquez, H. Gómez, R.E. Marotti, E.A. Dalchiele, Phyisica. Status Solidi A. 208, 1662, (2011).

14. D. Pradhan, K.T. Leung, Langmuir. 24, 9707, (2008).

15. J. Elias, R. Tena-Zaera, C. Lévy-Clément, Thin Solid Films. 515, 8553, (2007). 
16. JCPDS, 5-0664, ZnO.

17. JCPDS, 41-1445, $\mathrm{SnO}_{2}$.

18. R. Henríquez, P. Grez, E. Muñoz, H. Gómez, J. A. Badán, R.E. Marotti, E.A. Dalchiele, Thin Solid Films. 518, 1774, (2010).

19. R.E. Marotti, P. Giorgi, G. Machado, E.A. Dalchiele, Sol. Energy. Mat. Sol. Cells, 90, 2356, (2006).
20. Y. Zhao, K. Zhu, J. Phys. Chem. Lett. 4, 2880, (2013).

21. JCPDS, 65-2870, Au.

22. JCPDS, 87-0638, Pd.

23. M.A. Green, A. Ho-Baillie, H.J. Snaith, Nature. Photon. 8, 506, (2014)

24. Z. Wei, K. Yan, H. Chen, Y. Yi, T. Zhang, X. Long, J. Li, L. Zhang, J. Wang, S. Yang, Energy Environ. Sci. 7, (2014), 3326. 